\title{
JPEB
}

Jurnal Penelitian Ekonomi dan Bisnis, 4 (2), 2019, Hal: 153-165

http://www.jpeb.dinus.ac.id

\section{PENERAPAN E-PUSKESMAS PADA PUSKESMAS TANJUNGPINANG}

\author{
Satriadi $^{1 *}$ dan Dwi Septi Haryani ${ }^{2}$ \\ 1,2Jurusan Manajemen, STIE Pembangunan Tanjungpinang \\ Jalan Raja Haji Fisabilillah No. 34 Tanjungpinang, Indonesia \\ *Corresponding Email :satriadi456@gmail.com
}

Diterima: Mei 2019; Direvisi: Agustus 2019; Dipublikasikan: September 2019

\begin{abstract}
In the era of industrial revolution 4.0 which most of it integrated to the internet, of course technology information nowadays has becomes something that part of out needs for some people even for every one in this world. Every health services in an area of city must be capable to do the best, so the progress in giving health services to society could be so much effective. Health service that easily be found in an area or city is Puskesmas. Most people are often feeling so dissapointed to the activity progress in Puskesmas. However, this has been minimalized through using management information system which found in Puskesmas (e-Puskesmas). This research was held in Puskesmas Tanjungpinang. This research's purpose is to know the implementation of management information system (e-Puskesmas) in Puskesmas Tanjungpinang. Research method been done by doing obvservation and interview to health service activity that happened in Puskesmas. The result of this research is that management information system implementation in Puskesmas Tanjungpinang not yet fully integrated.
\end{abstract}

Keywords : Puskesmas; Management Information System; e-Puskesmas

\section{ABSTRAK}

Memasuki revolusi industri 4.0 yang seluruhnya terintegrasi dengan internet, tentu saja teknologi informasi saat ini telah dijadikan sebagai sesuatu yang sulit dilepas dari kebutuhan oleh sebagian bahkan seluruh umat manusia di dunia. Tiaptiap pelayanan kesehatan yang ada pada suatu daerah harus dapat melakukan upaya terbaik, agar proses pelaksanaan dalam memberikan layanan kesehatan terhadap masyarakat dapat berlangsung secara efektif. Pelayanan kesehatan yang mudah ditemui pada suatu daerah salah satunya ialah Puskesmas. Masyarakat sering mengalami rasa kecewa terhadap proses pelaksanaan aktivitas yang ada pada Puskesmas. Namun, hal ini diminimalisir melalui pemanfaatan Sistem Informasi Manajemen (SIM) yang terdapat pada Puskesmas, yakni e-Puskesmas. Penelitian ini dilakukan di Puskesmas Tanjungpinang.Penelitian ini bertujuan guna mengetahui implementasi sistem informasi manajemen yakni e-Puskesmas di Puskesmas Tanjungpinang. Metode penelitian dilakukan dengan melakukan observasi dan wawancara terhadap aktivitas pelayanan kesehatan yang terjadi di Puskesmas.Hasil dari penelitian yang dilakukan bahwa penerapan Sistem Informasi Manajemen yang terdapat di Puskesmas Tanjungpinang belum seluruhnya terintegrasi.

Kata Kunci : Puskesmas; Sistem Informasi Manajemen; e-Puskesmas 


\section{PENDAHULUAN}

Memasuki revolusi industri 4.0 yang seluruhnya terintegrasi dengan internet, tentu saja teknologi informasi saat ini telah dijadikan sebagai sesuatu yang sulit dilepas dari kebutuhan oleh sebagian bahkan seluruh umat manusia di dunia. Saat ini, tren komputerisasi mengalami perkembangan yang pesat, keseluruhan biaya atas penggunaan alat-alat di bidang kesehatan yang turut mengikuti perkembangan harus disesuaikan, peningkatan terhadap keefisiensian serta mutu layanan akan selalu dijadikan sebagai aspek yang penting guna meningkatkan daya saing dalam industri pelayanan kesehatan (Hsin Chang).

Pada bidang kesehatan sering sekali timbul berbagai macam persoalan-persoalan yang dapat memberikan pengaruh terhadap pengambilan keputusan (Ganing Anwar, Firdaus Muhammad). Organisasi Kesehatan Dunia mengungkapkan bahwa terdapat salah satu indikator dalam pembangunan atas kesehatan, yakni sistem informasi kesehatan dengan tujuan melakukan peningkatan terhadap kesehatan, respon, serta melakukan peningkatan terhadap efisiensi, sehingga sistem informasi ialah salah satu elemen yang menjadi penentu atas keberhasilan dari kerangka kesehatan (Ganing Anwar, Firdaus Muhammad).

Terkait dengan persoalan kesehatan yang terjadi, dalam hal ini pemerintah memiliki sebuah peran yang sangat dibutuhkan oleh masyarakatnya. Pemerintah daerah telah diikutsertakan dalam memberikan dukungan atas program-program kesehatan, seperti Jaminan Kesehatan Nasional (JKN) serta pengendalian jika terjadinya defisit terhadap Badan Penyelenggara Jaminan Sosial (BPJS) (S. Pohan Imbalo, Jaminan Mutu Layanan Kesehatan). Kewajiban pemerintah daerah ialah mengalokasikan APBD untuk anggaran kesehatan dengan persentase sebesar 10 persen guna memberika suatu dukungan terhadap rencana program dari JKN serta pengurangan atas defisit BPJS (S. Pohan Imbalo, Jaminan Mutu Layanan Kesehatan).

Bentuk perwujudan dari pemerintah pada bidang kesehatan yakni Dinas Kesehatan, Dinas Kesehatan membangun unit-unit kesehatan pada setiap daerah seperti rumah sakit, Puskesmas, posyandu, dan sebagainya. Salah satunya yakni Puskesmas yang mudah untuk ditemui di tiap-tiap daerah. Puskesmas memberikan suatu pelayanan berjangka pendek yang aktivitasnya terdiri atas aktivitas pengamatan, diagnosis atau melakukan identifikasi terhadap sesuatu hal yang dirasakan oleh orang yang merasakan sakit (Rohmah Mawadah).Dalam aktivitas penyelenggaraan manajemen kesehatan, Pusat Kesehatan Masyarakat atau dikenal dengan istilah Puskesmas merupakan ujung tombak atas pelayanan kesehatan (Sundari).

Kota Tanjungpinang memiliki enam Puskesmas yang memberikan pelayanan dasar terhadap masyarakat Tanjungpinang, yakni Puskesmas Sei Jang, Mekar Baru, Batu 10, Melayu Kota Piring, Kampung Bugis, dan Tanjungpinang (Al Jabar Sunda). Namun, hanya baru terdapat tiga Puskesmas yang telah menerapkan e-Puskesmas, yakni Puskesmas Tanjungpinang, Puskesmas Batu 10, dan Puskesmas Sei Jang, hal tersebut dikarenakan ketiga Puskesmas ini memiliki kunjungan pasien yang banyak jika dibandingkan dengan Puskesmas lainnya (Tribun).

Penggunaan terhadap e-Puskesmas merupakan suatu upaya yang memberikan solusi kepada pelaksana pelayanan kesehatan yakni Puskesmas sehingga mampu memberikan pelayanan kepada pasien dengan cepat, aktivitas pelaporan ke Dinas Kesehatan juga menjadi lebih cepat dikarenakan adanya sistem Online Reporting, memberikan kemudahan terhadap aktivitas sebelumnya manual menjadi digital, dan tentu saja mengefisiensikan masa dalam bekerja, dan sebagainya (Damayati, Santy Dwi, Rusmin Muhammad).

\section{TINJAUAN PUSTAKA \\ Puskesmas}

Puskesmas ialah salah satu instansi yang beroperasi di bidang pelayanan jasa kesehatan masyarakat, saat ini telah banyaknya pembangunan terhadap Rumah Sakit, namun untuk daerahdaerah yang terpencil atau desa yang masih memiliki Puskesmas, karena Puskesmas memiliki fungsi sebagai upaya pencegahan serta penanggulangan terhadap kesehatan masyarakat. 
Arti dari Puskesmas yakni suatu institusi kesehatan fungsional yang terintegrasi, yang berpusat terhadap pengembangan kesehatan masyarakat serta melakukan pembinaan selain memberikan pelayanan secara komprehensif dan terpadu terhadap masyarakat di area kerjanya yang membentuk aktivitas pokok.

Puskesmas juga memiliki makna sebagai unit penyelenggara Dinas Kesehatan Kabupaten/ Kota yang memiliki tanggungjawab atas penyelenggaraan pembangunan kesehatan pada suatu area kerja, sehingga dapat disimpulkan bahwa Puskesmas juga memiliki wewenang serta tanggung jawab atas pemeliharaan kesehatan masyarakat dalam area kerjanya.

Area kerja dari Puskesmas mencakup keseluruhan atas kecamatan maupun sebagian dari kecamatan yang ada, kemudian aspek-aspek seperti kepadatan penduduk, luas suatu daerah, keadaan geografis, dan keadaan terhadap infrastruktur merupakan aspek pertimbangan dalam melakukan penentuan terhadap area kerja Puskesmas. Puskesmas termasuk dalam perangkat pemerintah daerah Kabupaten/ Kota Madya, dan untuk sasaran masyarakat yang dilayani oleh suatu Puskesmas rata-rata sebesar 30.000 masyarakat pada tiap-tiap Puskesmas.

Dengan adanya Puskesmas pembantu dan Puskesmas keliling, akan membantu perluasan jangkauan terhadap Puskesmas sehingga perlu adanya aktivitas menunjang dalam unit pelayanan kesehatan. Puskesmas juga memiliki kedudukan yang sangat penting dalam penyelenggaraan teknis, dalam hal ini Puskesmas sebagai unit pelayanan kesehatan juga dituntut agar memiliki kemampuan manajerial serta pemikiran yang maju guna melakukan peningkatan terhadap kualitas pelayanan kesehatan, selain itu Puskesmas juga memiliki beberapa fungsi, yakni :

1. Titik utama terhadap pembangunan kesehatan pada masyarakat di area kerjanya;

2. Melakukan aktivitas pembinaan terhadap masyarakat di area kerjanya dengan tujuan melakukan peningkatan guna hidup sehat;

3. Menyediakan layanan kesehatan secara komprehensif dan terpadu terhadap masyarakat di area kerjanya.

Secara umum, Puskesmas memiliki susunan organisasi, yakni :

1. Kepala Puskesmas, memiliki tugas pokok serta fungsi dalam memimpin, melakukan tindakan pengawasan, serta melakukan tindakan koordinasi terhadap aktivitas Puskesmas;

2. Kepala Tata Usaha, memiliki tugas pokok serta fungsi pada bagian kepegawaian, finansial, perlengkapan yang dibutuhkan, korespondensi, pendataan, serta pelaporan;

3. Pelaksana, unit yang terdiri atas tenaga kerja atau pegawai yang jumlahnya dipengaruhi oleh aktivitas, tenaga, serta fasilitas pada tiap-tiap area kerja Puskesmas.

Pelaksanaan program pada Puskesmas disesuaikan dengan keahlian tenaga kerja serta sarana dan prasarananya, oleh karena hal itu program pokok yang ada pada setiap Puskesmas mengalami perbedaan. Pelaksanaan program-program yang terdapat di Puskesmas dapat dikembangkan atas dasar program pelayanan kesehatan yang telah dianjurkan oleh Organisasi Kesehatan Dunia yang dikenal dengan tujuh dasar, yakni perawatan kesehatan ibu dan anak, perawatan medis, pembudayaan hidup bersih dan sehat, pendidikan kesehatan, laboraturium sederhana, tindakan pengendalian penyakit yang menular, dan administrasi dasar yakni pencatatan serta pelaporan.

Selain itu, terdapat beberapa indikator-indikator yang dijadikan sebagai penentu atas mutu dari pelayanan, yakni :

1. Kehandalan, yakni dapat menimbulkan rasa percaya terhadap tindakan yang dilakukan oleh tenaga-tenaga medis dalam memberikan pelayanan secara cepat dan tepat kepada pasien, serta memiliki keterkaitan dengan keahlian dalam melakukan pelayanan yang dapat memberi kepuasan terhadap pasien;

2. Daya tanggap, yakni daya tanggap yang baik dapat dinilai dari ketika pasien sedang memerlukan bantuan maupun menyampaikan keluhan, dalam artian daya tanggap sendiri ialah sikap dari tenaga medis dalam membantu pasien yang sedang mengalami kesulitan serta kesiapan dari petugas dalam memberikan pelayanan dengan segera terhadap pasien; 
3. Tenggang rasa, yakni memiliki keterkaitan dengan perasaan perduli dan perhatian oleh tenaga medis terhadap pasien dengan memahami keperluan pasien;

4. Berwujud, seperti yang diketahui bahwa suatu usaha yang bersifat pelayanan atau jasa memerlukan sesuatu yang berwujud dalam aktivitas operasionalnya, dengan adanya perwujudan atas suatu pelayanan akan membantu pasien dalam melakukan penilaian terhadap mutu dari pelayanan kesehatan, misalnya seperti bangunan, sarana dan prasarana, serta penampilan tenaga medis yang berpakaian dengan rapi dan memiliki tanda pengenal.

\section{Sistem Informasi Manajemen}

Sistem yakni kesatuan dari berbagai macam komponen yang saling berkaitan dan ada didalam suatu wilayah dan memiliki item penggerak contohnya seperti negara. Negara merupakan suatu persatuan dari berbagai komponen kesatuan yang lain misalnya saja suatu provinsi yang saling berkaitan sehingga bisa menciptakan suatu negara dimana yang bertindak sebagai penggerak adalah rakyat yang ada didalam negara tersebut.

Sistem dapat diartikan sebagai sekumpulan komponen-komponen yang disatukan dengan yang lainnya agar tercapainya suatu tujuan yang diinginkan. Komponen-komponen yang dimaksudkan itu terdiri dari alat-alat mesin, metode, file, pengguna, data dan komponen lain yang terorganisir dari komponen-komponen tersebut.

Informasi merupakan pelajaran yang didapat dari suatu pemahaman, pengalaman, pendapat, bahkan dari suatu instruksi. Akan tetapi istilah tersebut mempunyai banyak sekali arti tergantung pada konteksnya pemahamannya. Terdapat berbagai hal pengetahuan mengenai kejadian-kejadian tertentu atau bahkan bisa dari suatu konteks yang telah dikumpul dan diterima yang melewati proses komunikasi, pengumpulan intelejen, dan bahkan didapat dari berita.

Arti atas informasi dapat disimpulkan, bahwa informasi yakni suatu data yang diolah, kemudian olahan data tersebut akan memberikan hasil yang nantinya akan dipergunakan oleh pengguna untuk pengambilan suatu keputusan.

Data ialah sumber dari informasi, data juga memiliki arti sebagai kenyataan yang mengilustrasikan atas peristiwa-peristiwa yang jelas, untuk selanjutnya dilakukan proses pengolahan data dengan mempergunakan model untuk menghasilkan sistem informasi, dan informasi akan menjadi sesuatu yang bermanfaat ketika informasi memiliki tiga pilar, yakni penerima informasi yang tepat, tepat waktu, dan akurat.

Di dalam institusi pasti memiliki yang namanya sistem informasi untuk memudahkan institusi dalam memperoleh informasi yang kemudian akan dapat digunakan untuk mengambil sebuah keputusan, sehingga ketika ingin mengambil sebuah keputusan akan lebih mudah dan tidak memerlukan banyak waktu kerena sistem akan mencari cara yang paling efisien.

Sebuah program yang terdapat pada komputer yang memiliki peran dalam mendukung kegiatan operasi yang terjadi pada suatu institusi, misalnya seperti software dan data. Dengan demikian, dapat diambil kesimpulan bahwa sistem informasi memiliki arti sistem yang mengkaitkan berbagai macam informasi dari berbagai sumber guna untuk membantu institusi dalam membuat keputusan secara cepat.

Sistem informasi manajemen memiliki makna sebagai proses komunikasi yang terdiri atas masukan, proses, serta keluaran (hasil) atau keputusan mengenai perencanaan, pengoperasian, serta pengawasan. Terdapat berbagai karakteristik dari sistem informasi manajemen yang perlu untuk diketahui, yakni :

1. Kuantitas informasi, yakni pengelolaan informasi yang dilakukan oleh sistem informasi manajemen harus memiliki kemampuan untuk memenuhi kebutuhan atas banyaknya informasi;

2. Mutu informasi, yakni pengelolaan informasi yang dilakukan oleh sistem informasi manajemen harus memiliki kemampuan untuk memenuhi kebutuhan atas mutu informasi;

3. Informasi aktual, yakni pengelolaan informasi yang dilakukan oleh sistem informasi manajemen harus memiliki kemampuan untuk memenuhi kebutuhan atas informasi yang baru; 
4. Informasi yang relevan, yakni pengelolaan informasi yang dilakukan oleh sistem informasi manajemen harus memiliki kemampuan untuk memenuhi kebutuhan informasi;

5. Kebenaran informasi, yakni pengelolaan informasi yang dilakukan oleh sistem informasi manajemen harus memiliki kemampuan untuk memenuhi kebutuhan informasi yang benar

\section{E-Puskesmas}

Puskesmas memiliki banyak sumber-sumber data yang dapat dijadikan sebagai suatu informasi guna pengambilan keputusan yang efektif, namun umumnya ketidak optimalan data terjadi pada aktivitas manajemen seperti perencanaan kegiatan, dan monitoring program, permasalahan atas Sistem Informasi Kesehatan di fasilitas kesehatan ialah tidak adanya pemanfaatan terhadap Sistem Informasi Manajemen Puskesmas (Simpuskesmas) (Nusa). Hal ini merujuk bahwa Simpuskesmas adalah bagian dari keformalitasan pelaporan yang harus dibuat, namun tidak sepenuhnya digunakan untuk pengambilan keputusan, Simpuskesmas memiliki arti sebagai aktivitas pencatatan dan pelaporan data-data umum, sarana, tenaga, dan berbagai upaya pelayanan kesehatan yang ada di Puskesmas yang memiliki tujuan atas ketersediaan seluruh data hasil aktivitas Puskesmas.

E-Puskesmas merupakan sistem informasi manajemen yang saat ini mengalami pengembangan dari Simpuskesmas yang terdapat di Puskesmas. Pembuatan e-Puskesmas sendiri sebagai bentuk dari upaya atas persoalan-persoalan yang diakibatkan oleh sistem manualyang umumnya dipergunakan, perancangan e-Puskesmas guna digitalisasi proses pelayanan kesehatan terhadap masyarakat di Puskesmas memberikan kemudahan terhadap sistem pelaporan atas data kepada Dinas Kesehatan serta memberikan kemudahan terhadap informasi secara efektif dan efisien melalui sistem online reporting.

Perancangan serta pengaplikasian e-Puskesmas memiliki suatu tujuan agar mudah untuk dipergunakan oleh seseorang yang jarang menggunakan perangkat komputer, ketersediaan fiturfitur yang terdapat pada e-Puskesmas diharapkan dapat memberikan kemudahan dan menggiatkan penggunanya pada Puskesmas di seluruh Indonesia sehingga dapat memberikan peningkatan terhadap kinerja secara nyata.

Dalam penggunaannya, hal pertama yang akan timbul ialah halaman Login yang merupakan bagian yang penting ketika hendak mempergunakan e-Puskesmas guna melakukan pemilihan terhadap aktivitas yang ingin dilakukan untuk selanjutnya, dan tentu saja tiap-tiap tingkatan pengguna akan memiliki perbedaan pada username dan password yang berguna untuk melakukan identifikasi terhadap bidang atau pengguna di Puskesmas.

\section{METODE PENELITIAN}

Jenis penelitian mempergunakan pendekatan secara kualitatif yang dilakukan dengan cara observasi dan wawancara. Observasi yang dilakukan ialah melakukan aktivitas pengamatan secara langsung terhadap mekanisme kerja yang terdapat pada Puskesmas Tanjungpinang dan wawancara guna melakukan pengumpulan terhadap informasi-informasi yang dibutuhkan dengan melakukan pembicaraan secara langsung dengan pihak-pihak yang terkait.

Dalam penelitian ini mempergunakan data primer serta data sekunder.Data primer diperoleh dari aktivitas wawancara langsung dengan beberapa informan yang berada di Puskesmas Tanjungpinang.Data sekunder diperoleh dari buku dan jurnal yang memiliki keterkaitan dengan objek penelitian yang diteliti dengan jumlah informan sebanyak 3 orang.

\section{HASIL DAN PEMBAHASAN}

Penelitian ini mendeskripsikan penerapan e-Puskesmas di Puskesmas Tanjungpinang yang dilakukan terhadap informan yang mengetahui dan ikut terlibat dalam proses pelaksanaan ePuskesmas, dengan jumlah informan sebanyak 3 orang. Berikut hasil wawancara dengan informan. 


\section{Penanggungjawab/ Atasan}

Bapak Jum'at selaku penanggungjawab dari operator sistem informasi manajemen yang ada di Puskesmas menyatakan bahwa aktivitas pelayanan kesehatan pada Puskesmas Tanjungpinang diawali dengan mempergunakan sistem yang manual. Kemudian dengan mengikuti perkembangan teknologi saat ini dan tuntutan dari masyarakat untuk melakukan peningkatan terhadap mutu dari pelayanan kesehatan, diperkenalkan infoKes yang berbasis android dan ePuskesmas yang berbasis website sebagai penunjang dari aktivitas pelayanan kesehatan. Penanggung jawab memiliki peran dalam penggunaan sistem informasi manajemen yang dimiliki, yakni memberikan bimbingan, arahan terhadap petugas e-Puskesmas agar pelaksanaan dalam penggunaannya lebih efektif dan efisien.

Namun, penggunaan e-Puskesmas di Puskesmas Tanjungpinang belum sepenuhnya optimal karena baru berjalan selama kurang lebih satu bulan, dan masih terdapatnya poli-poli klinik yang belum mempergunakan e-Puskesmas sehingga masih adanya penggunaan sistem manual dalam memberikan layanan terhadap masyarakat. Pengintegrasian sistem informasi manajemen yang ada pada Puskesmas Tanjungpinang ditargetkan akan menyeluruh penggunaannya pada seluruh poli-poli klinik pada tahun 2019. Perencanaan terhadap penggunaan e-Puskesmas awalnya direncanakan oleh Dinas Kesehatan yang kemudian diimplementasikan ke Puskesmas dan adanya aktivitas penyelenggaraan pelatihan terkait penggunaan e-Puskesmas yang diselenggarakan oleh Telkom Indonesia.

Mekanisme dari pengumpulan laporan yang dilakukan juga belum dapat optimal yang diakibatkan dari belum terintegrasinya penggunaan e-Puskesmas tersebut secara menyeluruh. Namun, walaupun penggunaan e-Puskesmas belum menyeluruh, aktivitas yang terjadi pada Puskesmas Tanjungpinang semakin baik.

Terutama mengenai data-data pasien yang berkunjung, keberadaan e-Puskesmas sangat membantu dalam hal adanya basis data terhadap data-data pasien sehingga jika pasien tersebut melakukan kunjungan kembali, tidak perlu adanya aktivitas pemasukan data secara manual lagi karena sudah memiliki basis data sebelumnya.

Terkait perbaikan-perbaikan yang terjadi dalam penggunaan terhadap e-Puskesmas, ada beberapa hal yang diperhatikan yakni melakukan persiapan atau meningkatkan keterampilan dari sumber daya yang ada. Sumber daya yang dimaksud seperti para tenaga medis diberikan pelatihan yang disesuaikan dengan bidang-bidangnya dan pengadaan alat-alat komputer.

Dalam hal ini, kendala yang dihadapi ialah Puskesmas Tanjungpinang memiliki kekurangan terhadap sumber daya manusia. Sehingga menyebabkan para tenaga medis yang ada melakukan pekerjaan secara merangkap dan tidak sesuai dengan kompetensi yang dimiliki.Hal ini dapat terjadi karena tidak adanya penambahan sumber daya manusia yang diperlukan dengan kesesuaian kompetensi dan sesungguhnya banyak sumber daya manusia yang berkompeten akan bidang tersebut. Namun sering kali hal ini dihalangi oleh suatu keformalitasan yang harus dilalui sebelumnya. Sehingga, banyak sumber daya manusia yang berkompeten namun mereka terhalangi oleh suatu keformalitasan.

Dengan demikian, menimbulkan suatu persepsi bahwa ketika seseorang ingin bekerja, keahlian yang dimiliki bukanlah hal yang utama, namun seberapa baik seseorang menjawab pertanyaan-pertanyaan secara tertulis tanpa memandang keahlian yang sebenarnya dimiliki. Oleh karena itu, pada PuskesmasTanjungpinang kekurangan akan sumber daya manusia yang dimiliki, sehingga terjadi kekeliruan terhadap penempatan tenaga medis yang tidak sesuai antara kompetensi dan bidangnya.

\section{Operator}

Bapak Sigit Ardiansyah telah menjadi seorang operator di Puskesmas Tanjungpinang selama satu bulan. Beliau telah mengikuti pelatihan-pelatihan terkait Sistem Informasi Manajemen Kesehatan yakni e-Puskesmas yang telah diselenggarakan oleh Dinas Kesehatan Kota Tanjungpinang selama satu hari dan pada Puskesmas Tanjungpinang selama tiga hari.Aktivitas 
pelatihan di Dinas Kesehatan hanya pemberian pembekalan dan kemudian penggunaan ePuskesmas di praktekkan langsung pada Puskesmas Tanjungpinang.

Selama menjadi operator, Bapak Sigit Ardiansyah juga mengalami hambatan yang ditemui ketika penggunaan e-Puskesmas sedang berlangsung.Hal tersebut dapat terjadi dikarenakan sistem yang belum terintegrasi secara menyeluruh atau seratus persen sehingga berdampak terhadap fitur antrian online, daftar pasien, dan lainnya.Namun, hambatan utama yang dirasakan ialah koneksi internet yang sering mengalami gangguan disaat penggunaan e-Puskesmas.

Dalam penggunaan e-Puskesmas juga terdapat beberapa mekanisme yang perlu diperhatikan, yakni mula-mula pasien mengambil nomor antrian, kemudian mendaftarkan diri dan selanjutnya melakukan pengisian terhadap nomor kartu keluarga (KK) yang sesuai dan jika pasien memiliki kartu BPJS, pasien dapat menyertakannya.Ketika terdapat perubahan-perubahan yang perlu disesuaikan oleh e-Puskesmas, seperti perubahan terhadap data-data pasien, dalam hal ini pasien harus senantiasa melakukan pembaharuan terhadap identitasnya dan ketika pasien mempergunakan BPJS, maka pembaharuan harus dilakukan setiap tiga bulan sekali guna kesesuaian data yang diperlukan oleh pihak Puskesmas dan Dinas Kesehatan.

\section{Pengguna}

Ibu Armini selaku pengguna dari e-Puskesmas merasakan perbedaan yang sangat signifikan disaat Puskesmas Tanjungpinang telah beralih dari sistem secara manual menjadi sistem yang telah terkomputerisasi. Hal ini dirasakan ketika adanya kebutuhan atas suatu data, maka data tersebut akan lebih mudah dalam memperolehnya. Ketersediaan atas sumber daya juga semakin baik karena tenaga medis yang ada telah diberikan pelatihan sehingga dapat meningkatkan efektivitas dalam bekerja dan kelengkapan atas sarana dan prasarana yang diperlukan untuk melakukan pengaksesan terhadap e-Puskesmas tersebut.

Dengan adanya sistem komputer juga lebih memudahkan aktivitas-aktivitas pelayanan kesehatan yang terjadi di Puskesmas Tanjungpinang, karena lebih efektif dan efisien dengan tingkat kesalahan data pasien juga akan lebih kecil dibandingkan dengan mempergunakan sistem manual. Dan, kelebihannya lagi bahwa dengan penggunaan e-Puskesmas tidak perlu lagi adanya kekhawatiran akan kehilangan data-data pasien karena e-Puskesmas telah memiliki sistem yang berbasis cloud computing, dan tidak perlu lagi melakukan instalasi aplikasi pada perangkat tertentu.

Selama penggunaan e-Puskesmas berlangsung, Ibu Armini tidak mengalami kesulitan namun terkadang terdapat hambatannya, yakni koneksi internet yang sering mengalami gangguan sehingga yang awalnya mempergunakan sistem komputer harus beralih lagi ke sistem manual.Oleh karena hal itu, dapat berdampak pada keterlambatan aktivitas pelayanan kesehatan yang terjadi di Puskesmas Tanjungpinang.Penggunaan terhadap e-Puskesmas juga telah memiliki keselarasan dengan kebutuhan pengguna yang ada di Puskesmas Tanjungpinang.

\section{Implementasi Sistem Informasi Manajemen}

Sistem informasi manajemen kesehatan atau e-Puskesmas memiliki sistem berbasis android dan juga berupa website, yakni:

\section{Sistem Berbasis Android}

1. Pada android, aplikasi e-Puskesmas diberi nama dengan infoKes. Berikut ini ialah tampilan awal ketika mempergunakan infoKes, pengguna dapat mengikuti arahan yang ada, dan mengklik "Lanjut". 


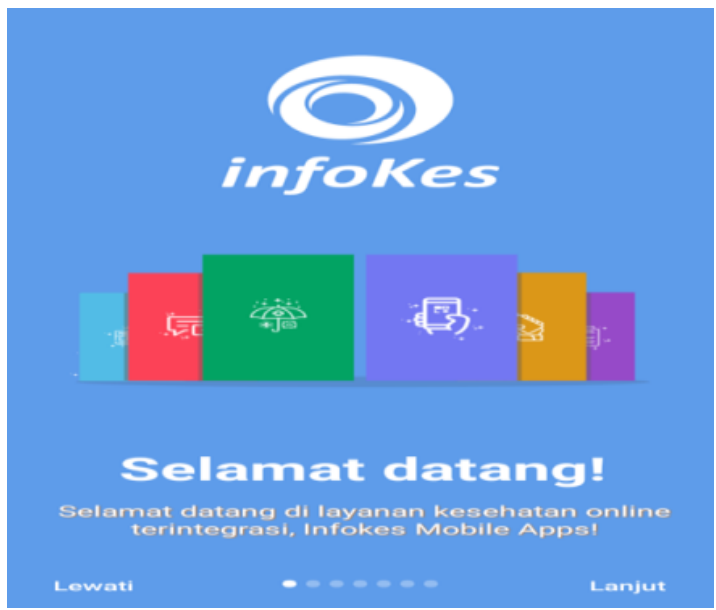

\section{Gambar 1. Tampilan Awal Aplikasi e-Puskesmas}

2. Setelah selesai, akan ditampilkan halaman mengenai kebijakan privasi dan ketentuan penggunaan, pengguna dapat melakukan tindakan centang pada kolom "Setuju", dan mengklik "Lanjut".

(口)

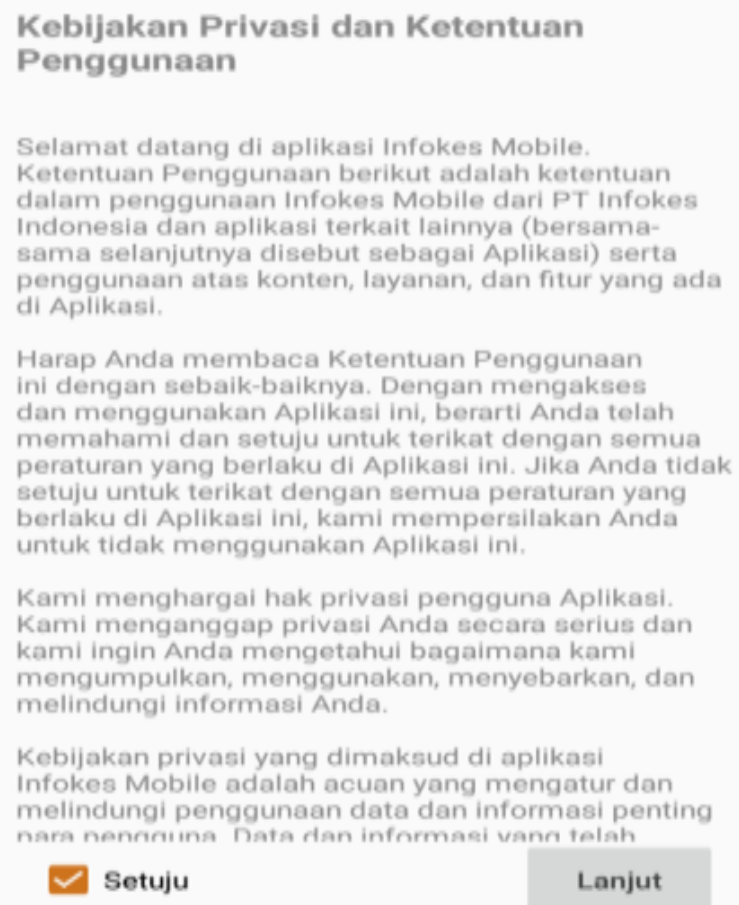

Gambar 2. Tampilan Halaman Tentang Kebijakan Privasi dan Ketentuan Penggunaan Aplikasi

3. Selanjutnya, akan adanya tampilan halaman "Login" dan pengguna dapat menggunakan akun facebook atau e-mail. 


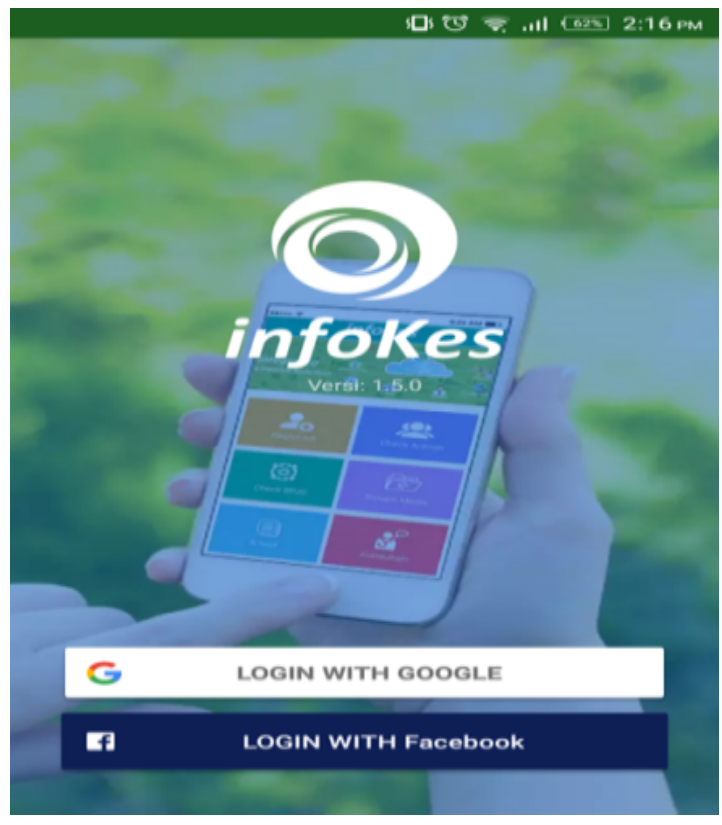

Gambar 3. Tampilan Halaman Login

4. Setelah melakukan aktivitas login, pengguna akan masuk ke halaman dashboard yang memiliki berbagai fitur-fitur yang disediakan oleh infoKes.
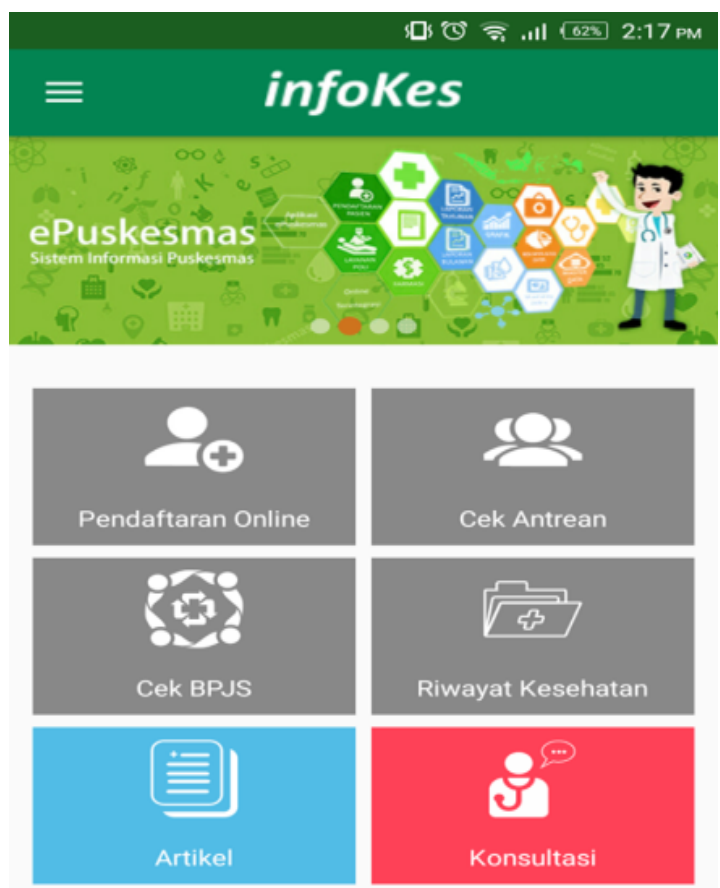

Gambar 4. Tampilan Halaman Dashboard

5. Ketika pengguna telah masuk ke halaman dashboard, pengguna harus melakukan aktivasi ulang akun, agar data yang dimiliki dapat terintegrasi dengan Puskesmas dan Dinas Kesehatan. Dengan cara, menggeser layar dari arah sebelah kiri, sehingga tampilan akan menjadi seperti ini. Untuk mengaktivasi ulang akun, pengguna dapat mengklik "Profil". 


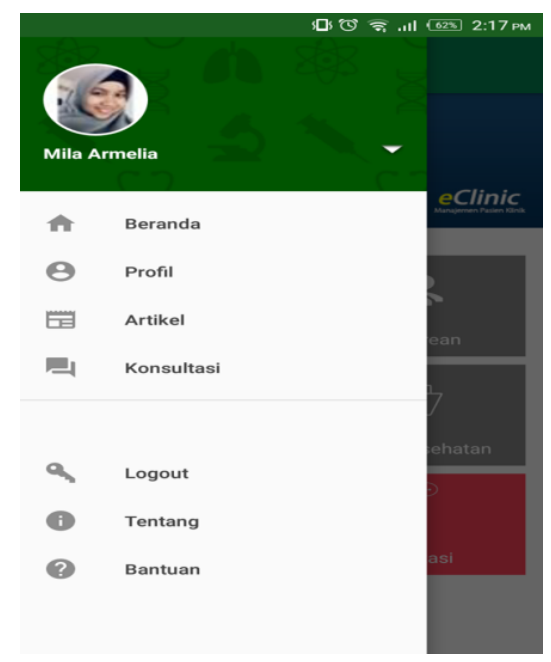

\section{Gambar 5. Tampilan Aktivasi Ulang Akun Pengguna}

6. Dibawah ini ialah tampilan "Profil" yang telah di klik tadi dan pengguna dapat mengisi kolom-kolom kosong sepertinomor KTP, nomor BPJS, tanggal lahir, e-mail terdaftar, alamat, dan Faskes terdaftaryang disesuaikan dengan data pengguna.

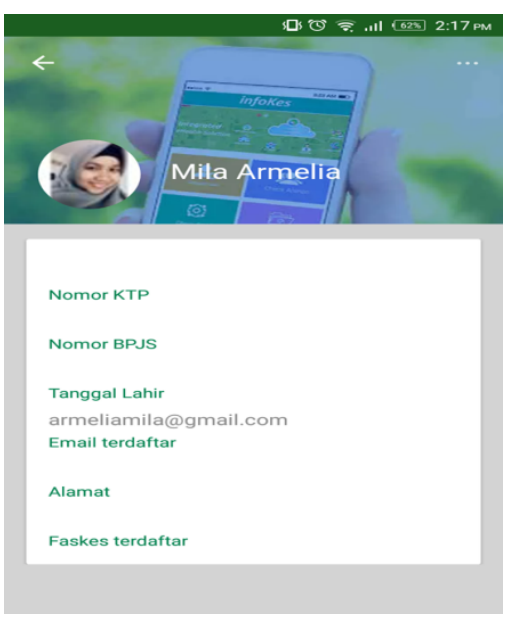

\section{Gambar 6. Tampilan Profil}

7. Setelah melakukan aktivasi ulang akun, pengguna dapat menikmati berbagai fitur yang disediakan oleh aplikasi infoKes, seperti artikel-artikel kesehatan dan melakukan konsultasi dengan dokter-dokter yang tersedia pada aplikasi infoKes. Seperti gambar yang ditampilkan di bawah ini.
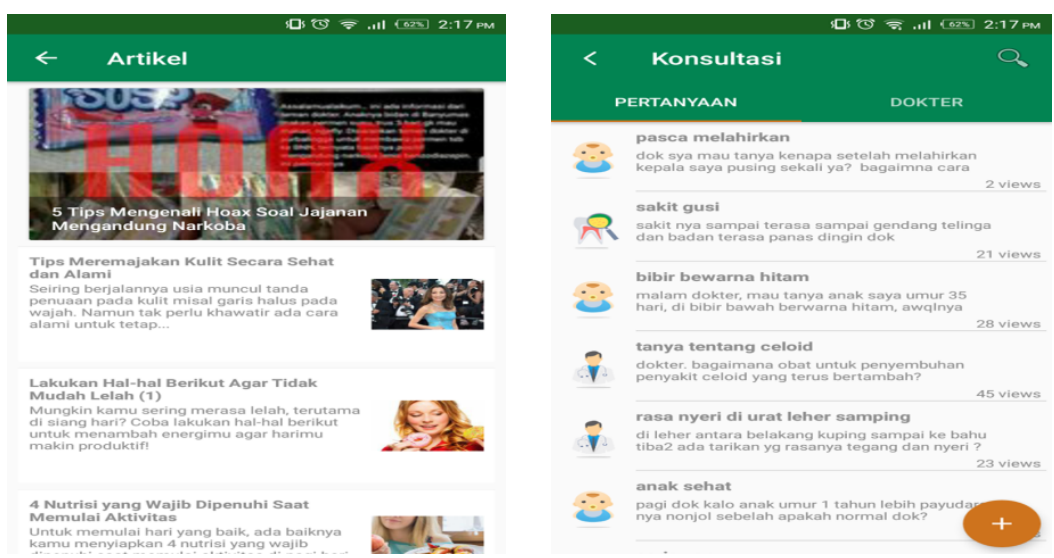

Gambar 7-8. Tampilan fitur aplikasi 


\section{Sistem berbasis website}

1. Pengguna dapat mengakses e-Puskesmas berbasis website, melalui alamat website tanjungpinang.epuskesmas.id yang ditampilkan seperti di bawah ini.

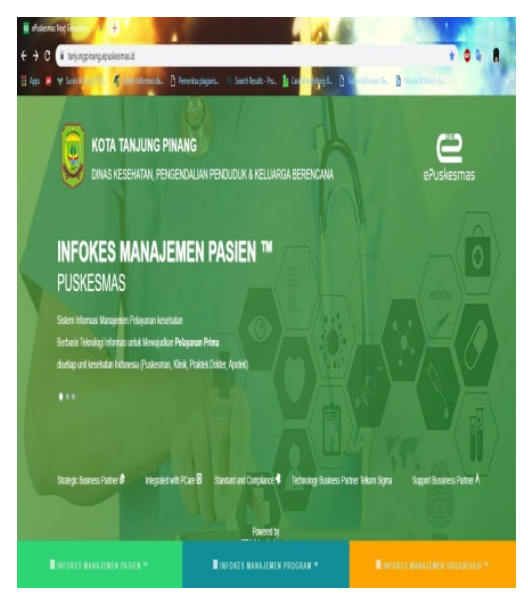

\section{Gambar 9. Halaman Awal Website}

2. Pada laman ini, pengguna dapat melakukan login dengan mengklik "infoKes manajemen pasien" dan mengklik "e-Puskesmas".

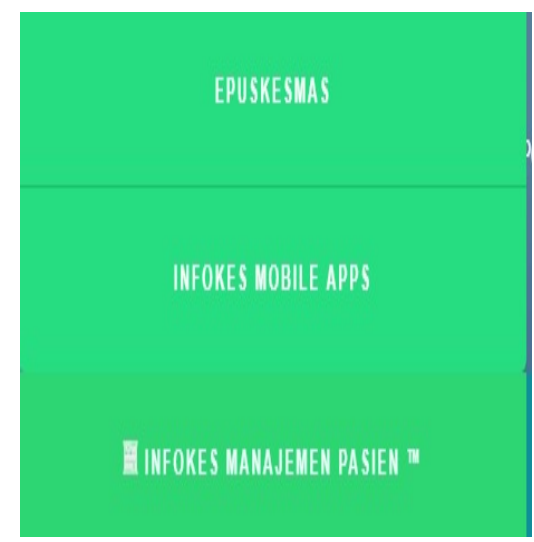

\section{Gambar 10. Langkah Login Website}

3. Maka, akan muncul halaman "Login" yang harus diisi sesuai dengan data yang telah didaftarkan sebelumnya melalui infoKes.

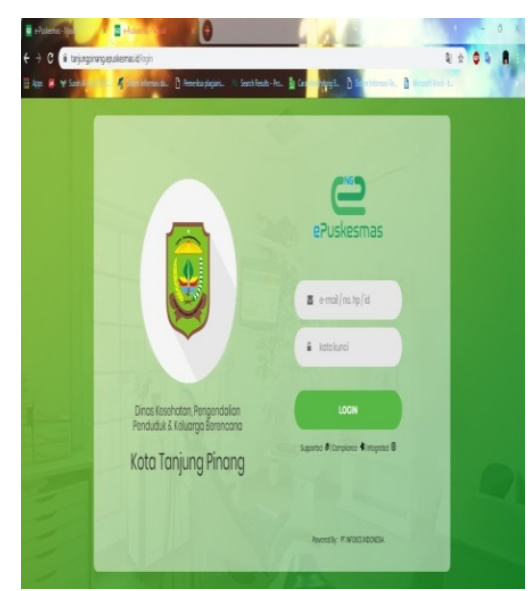

Gambar 11. Halaman Login Website 


\section{SIMPULAN}

Aktivitas pelayanan kesehatan pada Puskesmas Tanjungpinang dahulu mempergunakan sistem manual, namun karena hal perkembangan teknologi dan tuntutan masyarakat, Puskesmas Tanjungpinang melakukan pengembangan terhadap sistem informasi manajemen yang mereka miliki, dari sistem manual menjadi sistem berbasis android dan juga website yang dinamakan infoKes dan e-Puskesmas. Walaupun penggunaan e-Puskesmas belum sepenuhnya optimal, tetapi aktivitas yang terjadi pada Puskesmas Tanjungpinang berjalan semakin baik. Terutama adanya basis data terhadap data-data pasien sehingga tidak perlu dilakukannya pemasukan data secara manual lagi.Terkait perbaikan-perbaikan yang terjadi dalam penggunaan terhadap e-Puskesmas, ada beberapa hal yang diperhatikan yakni melakukan persiapan atau meningkatkan keterampilan dari sumber daya yang ada.Operator yang menjalankan sistem informasi manajemen pada Puskesmas Tanjungpinang telah mengikuti pelatihan yang terkait dengan hal tersebut.Namun, ketika penggunaan e-Puskesmas berlangsung, ditemui hambatan-hambatan yang dikarenakan sistem yang ada belum terintegrasi secara menyeluruh dan gangguan pada koneksi internet ialah hambatan utama disaat penggunaan e-Puskesmas sedang berlangsung.Pengguna dari e-Puskesmas merasakan perbedaan yang sangat signifikan disaat Puskesmas Tanjungpinang telah beralih dari sistem secara manual menjadi sistem yang telah terkomputerisasi. Hal ini dirasakan ketika adanya kebutuhan atas suatu data, maka data tersebut akan lebih mudah dalam memperolehnya.Dengan adanya sistem komputer juga lebih memudahkan aktivitas-aktivitas pelayanan kesehatan yang terjadi di Puskesmas Tanjungpinang, karena lebih efektif dan efisien dengan tingkat kesalahan data pasien juga akan lebih kecil dibandingkan dengan mempergunakan sistem manual.

Sebaiknya Dinas Kesehatan Kota Tanjungpinang memperhatikan tenaga kerja yang diperlukan di Puskesmas Tanjungpinang.Seperti, melakukan aktivitas rekrutmen terhadap tenaga kerja yang memiliki keselarasan terhadap keahliannya terutama pada bidang kesehatan.Sehingga aktivitas pelayanan kesehatan yang terjadi di Puskesmas Tanjungpinang dapat berjalan secara lebih efektif dan efisien.

\section{DAFTAR PUSTAKA}

Al Jabar Sunda. Daftar Puskesmas Di Kota Tanjungpinang Provinsi Kepulauan Riau. 2015.

Bagus, Saputro Arya, Fachri Adnan, dan Alhadi Zikri. 2017. Pelaksanaan Layanan E-Puskesmas Di

Puskesmas Ambacang Kecamatan Kuranji Kota Padang. Public Sector Innovations. 2: p. 10.

Cahyanti, Nur Ana, dan Eka Purnama Bambang. 2012. Pembangunan Sistem Informasi Manajemen

Puskesmas Pakis Baru Nawangan. Sentra Penelitian Engineering Dan Edukasi. 4: 5.

Calundu Rasidin. Manajemen Kesehatan. 2018. CV. Sah Media.

Damayati, Santy Dwi, Rusmin Muhammad, dan Arranury Zilfadhilah. 2015. Penerapan Sistem Informasi Manajemen Kesehatan Berbasis WEB Di Puskesmas Kota Makassar. Public Health Science Journal. 7:3.

Darmawan, Deni, dan Nur Fauzi Kunkun. Sistem Informasi Manajemen. 2013. PT Remaja Rosdakarya.

Efendy Ferry, dan Makhfudli. Keperawatan Kesehatan Komunitas. 2009. Salemba Medika.

Ganing Anwar, Firdaus Muhammad, dan Chairunisa Frida. 2017. Efektivitas E-Puskesmas Di

Puskesmas Kassi Kassi Kota Makassar. Administrasi Negara. 23

Hsin Chang, dan Chang Sheng. 2008. An Assessment of Technology-Based Service Encounters \&

Network Security on The e-Health Care Systems of Medical Centers in Taiwan. BMC Health

Services Research. 8

Jogiyanto. Sistem Informasi Manajemen. 2017. Universitas Terbuka.

Leonard, Devid. 2018. Analisis Pemanfaatan E-Puskesmas Dengan Metode PIECES Di Puskesmas 
Kota Padang. 1.

Nugroho, Eko. Sistem Informasi Manajemen. 2008. Yogyakarta: Penerbit Andi.

Nusa, Putra Hendra. 2018. Analisis Pelaksanaan Sistem E-Puskesmas Dengan Menggunakan Metode PIECES Di Puskesmas Pemancungan Padang Tahun. 1.

Rochaety, Eti. Sistem Informasi Manajemen.2013.Mitra Wacana Media.

Rohmah Mawadah, Dan Khumaidi A. 2016. Implementasi Kebijakan SIM Puskesmas Dalam Usaha Meningkatkan Pelayanan Masyarakat Pada Pekon Ringin Jaya Berbasis Website.Sistem Informasi STMIK Pringsewu Lampung.

S. Pohan Imbalo. Jaminan Mutu Layanan Kesehatan. 2007.

Sharma Atul, Kumar Rana Saroj, dan Rajesh Kumar. 2016. Quality of Health Management Information System for Maternal \& Child Health Care in Haryana State India.

Siyoto, Sandu, dan Supriyanto. Kebijakan Dan Manajemen Kesehatan. 2015. Yogyakarta: Penerbit Andi

Sundari, Jenie. 2016. Sistem Informasi Pelayanan Puskesmas Berbasis Web. Indonesian Journal on Software Engineering. 2.

Tribun, Batam. Tiga Puskesmas Di Tanjungpinang Akan Terapkan Pendaftaran Online Berbasis Android. 2017.

Wibisono, Setyawan, dan Munawaroh Siti. 2012. Sistem Informasi Manajemen Puskesmas (Simpuskesmas) Berbasis Cloud Computing. Teknologi Informasi DINAMIK. 17. 